\title{
Texture contrast soils (TCS) as indicators of eolian dust inputs in the coastal area of west central Senegal, West Africa
}

\author{
Aïdara C. A. Lamine Fall *
}

Department of Geography, Assane Seck University of Ziguinchor, BP 523 Ziguinchor, Senegal

\section{Article Info}

Received : 14.03 .2019

Accepted : 09.05.2020

\begin{abstract}
Different hypotheses have been addressed to explain the origin of texture contrast soils (TCS) in coastal regions. Our study investigates the TCS in the coastal region of west central Senegal, West Africa, in order to appreciate the influence of eolian dust inputs on their formation and characteristics. Nine soil profiles, from a levee to backswamp toposequence, three on each landscape position; floodplain, low terrace and middle terrace, were investigated. Soil profiles were described according to the World Reference Base. Particle-size analysis was performed by wet-sieving for the sand fraction and pipette analysis for the silt and clay fractions. Elements were determined in finely powdered soil mixed with cellulose in a ratio of $2: 1$. In this work, we focused principally on elemental zircon (Zr) and Titan (Ti). Our results show the presence of TCS in the coastal area of west central Senegal. We attribute the formation of these TCS to mainly two different sources of soil material: marine and continental. Marine sediments build the floodplain profiles and the subsoil of low terrace profiles, while the colluvial material derived from continental uplands form the middle terrace profiles and the topsoil of low terrace profiles. The main finding remains the influence of eolian dust inputs on the formation of TCS in this coastal area. Evidence of dust addition was confirmed by the uniformity of soil parent material tested through $\mathrm{mS} /(\mathrm{cU}+\mathrm{mU})$ and $\mathrm{Ti} / \mathrm{Zr}$ ratios. Such knowledge enhances understanding of local pedogenesis and may help develop sustainable soil management strategies.
\end{abstract}

Keywords: Eolian dust inputs, Senegal, texture contrast soil, West Africa.

(C) 2020 Federation of Eurasian Soil Science Societies. All rights reserved

\section{Introduction}

Early evidenced by Milne (1936), Ahn (1970), and Jones and Wild (1975) in coastal areas of West Africa, soil "catenas" or toposequences are characterized by contrasting pedo-environmental conditions between upand lowlands; sediments depleted and elements leached uplands accumulate lowlands, giving rise to variable soil properties along the same toposequence. Soil differences in landscapes have their primary origin in topographic position (Birkeland, 1999). Many authors highlighted the influence of topography or landscape position on soil formation and properties (Mulugeta and Sheleme; 2010; Baskan et al. 2016; Tijjani and Hassan, 2017). Understanding of soil forming factors (e.g. parent material, climate, topography, vegetation and time) is crucial to define physical, mineralogical and morphological properties of soils (Tunçay et al., 2020). Topographic positions or physiographical units have important role in soil formation and affects how water and energy were added to and was lost from soil systems (Dengiz and Şenol, 2018).

Abate and Kibret (2016) analysed the "effects of land use, soil depth and topography on soil physicochemical properties along the toposequence at the Wadla Delanta massif, northcentral highlands of Ethiopia" and found that topography of agricultural fields can influence soil physicochemical properties (soil depth, texture, and mineral contents), biomass production, incoming solar radiation, precipitation and affect crop production. As an increased topography/elevation significantly increased soil moisture, precipitation, soil

* Aïdara C. A. Lamine Fall cherif.fall@univ-zig.sn

(D) : $0000-0003-3478-2154$

(Corresponding author) 
organic matter and labile carbon, whereas bulk density, $\mathrm{pH}$ and soil temperature were significantly lower at the higher elevations. Topography is, therefore, central to the catena concept of soil development which is characterized by leaching and redistribution of soil material and elements down hill slopes (Baskan et al., 2016).

Another critical factor, which characterizes "catenas" in West Africa, remains the continental and marine influences they permanently face. This most often results in the formation of vertical texture contrast soils (TCS). The development of these TCS, whereby coarser surface material overlies finer subsurface layers, is still debated. Despite common occurrence, a definitive explanation for the formation and development of this characteristic is yet to be elucidated (Bald, 2012). The traditional explanation relies on eluviation and illuviation by downward-moving water. In this model, material removed from upper soil layers in solution is translocated to the illuvial horizon, where some of the solutes precipitate (sometimes termed neoformation). Also, fine-grained particles may be physically washed from upper to lower soil horizons (lessivage or argilluviation). This translocation depletes upper and enriches lower horizons in fines, creating the texture contrast. Erosion and deposition can account for some of these profiles, as can the inheritance of textural contrasts from sedimentary layering or lithological boundaries (Phillips, 2001).

It should also be mentioned that TCS are usually associated with a range of management problems including waterlogging, poor crop establishment, crusting, poor root penetration, desiccation, wind erosion, water erosion, tunnel erosion, salinity, and poor nutritional status. In addition, TCS are naturally very hard setting and suffer low infiltration rates and poor water holding capacity, which is accentuated where excessive cultivation has occurred. The presence of massive, poorly drained subsoils results in regular seasonal waterlogging, which results in poor aeration for roots, nitrogen deficiency, and increased manganese levels where $\mathrm{pH}$ is low. Reduced crop yields in TCS result from soil erosion, crusting, limited rooting capacity, poor aeration resulting from the slow movement of soil water through the upper B horizon, and confining of roots to shrinkage cracks and ped faces in the subsoil. In landscapes with sufficient slope, perched water-tables may be exacerbated by lateral movement of water on the upper surface of the B horizon leading to waterlogging and salinity in lower parts of the landscape (Hardie et al., 2012). The interpretation of such textural boundaries is important in a number of geomorphological contexts, such as distinguishing pedological vs. geological layering, the identification of colluvial and other geomorphic processes, and the interpretation of weathering profiles. The formation of TCS is important beyond the study of soil geomorphology and pedogenic processes in specific soils precisely because TCS are so widespread. Explaining the occurrence of TCS in a variety of environmental settings has been an important goal for pedologists and geomorphologists because such an explanation might elucidate general principles of soil development (Phillips, 2007).

This study aims to investigate the formation of TCS in the coastal area of west central Senegal, West Africa in order to appreciate the influence of eolian dust inputs on their development and characteristics. Such knowledge may enhance understanding of pedogenesis in coastal areas of West Africa, and worldwide at large, and will help develop sustainable soil management strategies. Landscapes position influences runoff, drainage, soil temperature, soil erosion, soil depth and hence soil formation. Different soil properties encountered along landscapes will affect the patterns of plant production, litter production and decomposition, which will definitely have effects on carbon (C) and nitrogen (N) contents of the soil (Mulugeta and Sheleme, 2010).

\section{Material and Methods}

\section{Presentation of the study area}

As a natural region, West Africa may be defined as lying south of the Ahaggar-Tibesti Mountains and west of the watershed separating Lake Chad from the Nile and Zaire drainage basins. West Africa thus lies west of the topographic demarcation of high Africa from low Africa. Geomorphologically, the West African region includes the coastal plain, the Guinea basement shields and the Taoudeni and Chad basins in the Western Sahara (Petters, 1991). The young geological evolution of West Africa is strongly marked by successive transgression and regression phases corresponding to changes in the Atlantic level during the Quaternary. They contribute to the construction of the main sedimentary units which intervene in the evolution of this littoral environment (Barusseau et al., 1995).

The coastal region of west-central Senegal, West Africa, is bounded on the west by the Atlantic Ocean (Figure 1). The climate is of Sudano-Sahelian type with a high mean annual temperature of $29^{\circ} \mathrm{C}$ and a mean annual

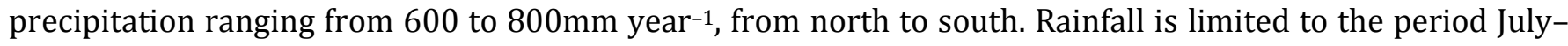
September (rainy season) (Faye et al., 2003). The geology consists of Holocene marine sediments underlain 
by Miocene deposits known as the 'Continental Terminal', a thick series of ferruginised and argillaceous sandstones, mudstones and carbonaceous layers, deposited under fluviatile and lacustrine conditions (Wright et al., 1985), which has undergone a profound ferrallitic pedogenesis (Michel, 1975; Kalck, 1978; Lappartient, 1985; Diop, 1986). The hydrologic system is the Saloum River, a tide-influenced inverse estuary', fed only by a limited river flow for 2-3 months during the rainy season (Faye et al., 2003). Hydrodynamics are essentially governed by the penetration of the tidal wave and the strong evaporation regime, which develop in the vast system of the interconnected tributaries (locally known as 'bolons') and the mangrove forest within the delta (Barusseau et al., 1995).

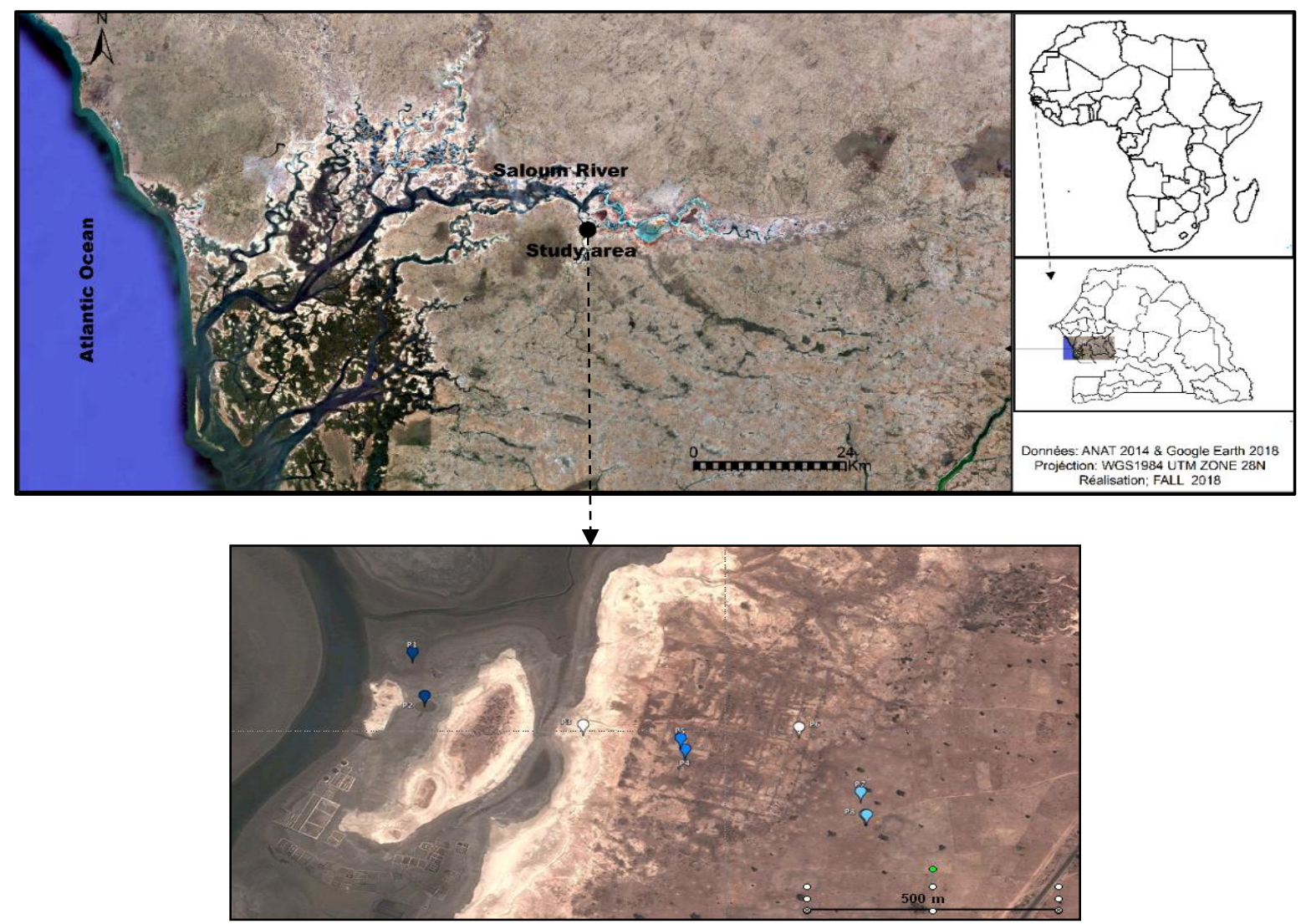

Figure 1. Location map of the study area with indication of soil profiles (from P1, left to P9, right) along the investigated transect (adapted from Google Earth, 2019).

The study site consists on a toposequence of $\sim 1.5 \mathrm{~km}$ length with a general slope of $0.5 \%$. The transect is oriented east-west and runs across a tributary of the Saloum River. At the lower part of the toposequence (floodplain), the soils are flooded and entirely devoid of vegetation. This area was formerly occupied by mangrove vegetation, with plant remnants as a prominent landscape feature (Lézine, 1997). Nearby, salt extraction activities using tiny evaporated ponds indicate a high level of salinity in the groundwater system. At the intermediate part (low terrace) we find seasonal salt-tolerant grasses like Phyloxerus vermicularis and Schoenefeldia gracilis. At the higher part (middle terrace), there is annual and perennial vegetation with the dominance of Balanites aegyptiaca (Fall et al., 2014).

\section{Field observations and measurements}

The selected toposequence was placed in such a way that influences of the landscape position could be reflected in soil properties. Nine soil profiles were distributed along the toposequence, three on each landscape position, i.e. floodplain, low terrace and middle terrace. All soil profiles were described in the field according to the World Reference Base (IUSS Working Group WRB, 2014). The Munsell soil colours were determined on moist samples. In total, 45 soil samples, one per identified horizon, were collected for laboratory analyses. The topography of the catena was determined using a theodolite.

\section{Particle-size and elemental analysis}

Particle-size analysis was performed after removal of carbonates and organic matter by treatment with $\mathrm{HCl}$ ( $\mathrm{pH} 4.5)$ and $\mathrm{H}_{2} \mathrm{O}_{2}(10 \%)$, respectively, and of excessive salts by repeated addition of deionised water, centrifugation and decantation until the EC dropped below $40 \mathrm{mS} \mathrm{cm}^{-1}$ (Schlichting et al., 1995). After subsequent addition of ammonia $\left(\mathrm{NH}_{3}\right)$ for water dispersion, overnight shaking and ultrasonic treatment, 
the sand fractions $(63-2000 \mu \mathrm{m})$ were obtained by wet-sieving, and the silt $(2-63 \mu \mathrm{m})$ and clay $(<2 \mu \mathrm{m})$ fractions were separated by pipette analysis after Köhn (Schlichting et al., 1995).

Elements were determined in all samples using Siemens SRS 200 X-ray fluorescence (XRF), (Bruker AXS $\mathrm{GmbH}, \mathrm{D}-76187$, Karlsruhe, Germany). In this method the $<2 \mathrm{~mm}$ soil samples were ground to fine powder and mixed with cellulose in a ratio of 2:1. Soil-cellulose samples were then analysed against standards to obtain the concentration of the elements which were further converted to their oxide forms using relevant factors. For the purpose of this work, we focused principally on elemental zircon (Zr) and Titan (Ti).

All soil analyses were performed in duplicate on the fine earth fraction $(<2 \mathrm{~mm})$. Results are expressed on the basis of the oven-dry $\left(105^{\circ} \mathrm{C}\right)$ soil weight. All graphics were performed using the Excel software, 2013.

\section{Results and Discussion}

\section{Soil morphology and particle-size distributions}

Detailed particle-size analyses allow a considerable insight into the origin and fate of soil parent materials (Walker et al., 1988). Solonchaks on the floodplain show a fine texture (silt clay loam). The clay content is higher in the central horizons of P1 and P2, but increases continuously with depth within P3 (Figure 2). The silt fraction decreases with depth throughout all profiles, with higher content in the topmost horizons compared to the underlying horizons. The sand fraction shows irregular distribution trend, increasing and decreasing alternately with depth throughout all profiles. This fraction is dominated by the fine sand ( $f S>m S>c S$ ), while the silt fraction is mostly coarse $(c U>m U>f U)$. The fine texture of the floodplain soils supports less permeability on this lowest landscape position. The low terrace soils, classified as Haplic Gleysol (Thionic), are characterized by sandy loam upper horizons and sandy clay loam lower horizons. The clay fraction increases, thus, downward in these profiles while the sand fraction shows an opposite trend, decreasing downward throughout all profiles. It is dominated by the fine sand fraction ( $\mathrm{fS}>\mathrm{mS}>\mathrm{cS}$ ). The silt fraction decreases slightly with depth throughout P4 and P5, but increases slightly throughout P6 (Table1, Figure 2). It is also dominated by the coarse silt fraction (cU>mU>fU). Soil material becomes coarser in the Endogleyic Arenosols on the middle terrace, from loamy sand to sand (Figure 2).

First interpretation of particle size distribution within soil profiles along the investigated toposequence suggests homogenous soil material on the floodplain and the middle terrace sites, and texture-contrasted soil on the low terrace site. This trend suggests the presence of TCS on this intermediate landscape position (Figure 2). The origin and formation of such TCS remains controversial. Some workers (Retallack, 1990; Birkeland, 1999) linked it to in situ weathering processes, from which, eluviation/illuviation has typically been perceived as the major. It is based on field evidence of cutans; coatings or accumulations on ped faces, in pores, or on particle surfaces (Phillips, 2001). Another evidence of eluviation-illuviation includes increases in fine clay/total clay ratios with depth in the absence of lithologic discontinuities, and oriented clay in thin sections (Langley-Turnbaugh and Bockheim, 1997). Other workers (Paton et al., 1995) maintain however that illuviation is inadequate as a general explanation for the development of TCS. The most fundamental line of their argument is evidence that in many soils there is simply too much clay in the subsoil to have been derived from the overlying horizons. They support the existence of processes other than eluviation-illuviation that may be of comparable or greater importance in creating TCS. Phillips (2001) identified five general explanations for the development of TCS: (1) vertical contrasts inherited from parent material, (2) deposition of coarse surface layers, (3) erosional winnowing, (4) eluviation-illuviation, and (5) bioturbation. The second explanation supports TCS inherited from sedimentary layering. It seems more consistent with our findings and may help explain the nature and stratification of sediments in the low terrace profiles. The three (3) criteria retained by Phillips (2001) to identify TCS in the Nacogdoches County, Texas: (1) A and/or E horizon texture of sandy loam or coarser, (2) B horizon texture of sandy clay loam or finer, and (3) a difference of at least three textural classes between the surficial and B horizon; are thoroughly met on this transitional landscape position. These profiles read from the bottom upwards, record a sequence of soil material with silt clay loam sublayers overlain by sandy loam upper layers (Figure 2). Confirmation of this hypothesis requires however uniformity tests of soil parent material.

\section{Uniformity tests}

Uniformity tests were performed to confirm the textural contrasts suspected in the low terrace profiles on the basis of particle-size distribution, whereby inferring the origin and nature of sediments in the study area. The main reason why parent-material uniformity is important is that it provides clues as to the original particle size distribution of the soil in question (Birkeland, 1999). Uniformity of the parent material was tested through sedimentologic $(\mathrm{mS} / \mathrm{cU}+\mathrm{mU})$ and geochemical $(\mathrm{Ti} / \mathrm{Zr})$ parameters. 
Table 1. Selected soil characteristics along the investigated toposequence

\begin{tabular}{|c|c|c|c|c|c|c|c|c|c|}
\hline \multirow{2}{*}{$\begin{array}{l}\text { Depth } \\
(\mathrm{cm})\end{array}$} & \multirow{2}{*}{ Horizon } & \multirow{2}{*}{$\begin{array}{l}\text { Colour } \\
\text { (moist) }\end{array}$} & \multicolumn{3}{|c|}{ Texture (\%) } & $\mathrm{Ti}$ & $\mathrm{Zr}$ & $\mathrm{TiO}_{2}$ & $\mathrm{ZrO}_{2}$ \\
\hline & & & Sand & Silt & Clay & \multicolumn{2}{|c|}{ ppm } & \multicolumn{2}{|c|}{$\%$} \\
\hline \multicolumn{10}{|c|}{ Floodplain (P1), Gleyic Hyposalic Solonchak (Sulphatic), 14º 04' 27.4” N / 016. 11' 17.4" W } \\
\hline $0-1$ & $\mathrm{Az}$ & $7.5 Y 4 / 1$ & 24.5 & 56.7 & 18.8 & 3636 & 397 & 0,6 & 0.05 \\
\hline $1-4$ & $\mathrm{Bjz}$ & 7.5YR5/6 & 25.6 & 37.4 & 37.0 & 5064 & 544 & 0,8 & 0.10 \\
\hline $4-23$ & Bjv & 7,5YR4/2 & 17.9 & 34.8 & 47.2 & 5864 & 550 & 1,0 & 0.10 \\
\hline $23-60$ & $\mathrm{Bv}$ & 10YR3/3 & 29.4 & 31.4 & 39.2 & 5612 & 465 & 0,9 & 0.10 \\
\hline \multicolumn{10}{|c|}{ Floodplain (P2), Gleyic Hypersalic Solonchak (Sulphatic), 14º 04' 23.8'” / 016. 11' 16.6”'W } \\
\hline $0-1$ & Azm & $5 Y 3 / 1,5 Y R 5 / 8$ & 22.8 & 45.7 & 31.5 & 1780 & 168 & 0,3 & 0.02 \\
\hline $1-8$ & $\mathrm{Az}$ & $2.5 \mathrm{Y} 4 / 1$ & 27.6 & 32.9 & 39.4 & 5225 & 477 & 0,9 & 0.10 \\
\hline $8-30$ & Cjr & 2.5YR3/1 10YR7/6 & 21.3 & 30.7 & 47.7 & 6450 & 594 & 1,1 & 0.10 \\
\hline $30-60$ & $\mathrm{Cr}$ & 7.5YR2/2 & 42.3 & 30.5 & 27.2 & 4151 & 440 & 0,7 & 0.10 \\
\hline \multicolumn{10}{|c|}{ Floodplain (P3), Gleyic Hyposalic Solonchak (Sulphatic), 14º 04' 21.4” N / 016. 11' 06.0”W } \\
\hline $0-5$ & Ahz & 7.5YR5/4 & 75.2 & 21.6 & 3.2 & 2814 & 957 & 0,5 & 0.10 \\
\hline $5-11$ & $\mathrm{Cz}$ & 10YR7/2 & 69.8 & 25.9 & 4.3 & 2978 & 826 & 0,5 & 0.10 \\
\hline $11-17$ & $\mathrm{C}$ & 10YR6/4 & 79.5 & 17.8 & 3.1 & 2132 & 660 & 0,4 & 0.10 \\
\hline $17-26$ & $\mathrm{Bl} 1$ & 7.5YR5/8 & 83.6 & 10.7 & 6.1 & 1238 & 278 & 0,2 & 0.04 \\
\hline $26-34$ & $\mathrm{Bl} 2$ & mottled & 78.9 & 12.2 & 8.8 & 1584 & 328 & 0,3 & 0.04 \\
\hline $34-70$ & Bhr & 7.5YR2/1 & 64.3 & 11.0 & 24.7 & 2911 & 295 & 0,5 & 0.04 \\
\hline \multicolumn{10}{|c|}{ Low Terrace (P4), Haplic Gleysol (Thionic), 1404' 19.4” N / 016. 10'59.2”W } \\
\hline $0-2$ & Ah1 & 7.5YR3/3 & 57.2 & 26.4 & 16.3 & 3490 & 421 & 0,6 & 0,1 \\
\hline $2-16$ & Ah2 & 10YR4/4 & 57.9 & 18.3 & 23.7 & 3706 & 439 & 0,6 & 0,1 \\
\hline $16-38$ & $\mathrm{Bl} 1$ & $7.5 \mathrm{YR} 4 / 3$ & 61.8 & 18.3 & 20 & 3559 & 476 & 0,6 & 0,1 \\
\hline $38-62$ & $2 \mathrm{Bl} 2$ & $10 \mathrm{R} 4 / 3$ & 45.8 & 23.3 & 30.9 & 5052 & 467 & 0,8 & 0,1 \\
\hline $62-90$ & $2 \mathrm{Bl} 3$ & $5 Y 6 / 1$ & 46.0 & 21.3 & 32.7 & 4863 & 441 & 0,8 & 0,1 \\
\hline $90-100$ & $2 \mathrm{Brl}$ & $2.5 Y 5 / 2$ & 41.8 & 23.6 & 34.6 & 4989 & 436 & 0,8 & 0,1 \\
\hline \multicolumn{10}{|c|}{ Low Terrace (P5), Haplic Gleysol (Thionic), $14^{\circ} 04^{\prime} 20.3^{\prime \prime} \mathrm{N} / 16.10^{\prime} 59.5^{\prime \prime} \mathrm{W}$} \\
\hline $0-2$ & Ahz1 & 10YR3/3 & 70.4 & 19.7 & 9.7 & 2567 & 456 & 0,4 & 0,1 \\
\hline $2-11$ & Ahz2 & 10YR3/4 & 62.5 & 18.3 & 19.1 & 2847 & 307 & 0,5 & 0,04 \\
\hline $11-29$ & Bwz & 10YR4/6 & 46.7 & 22.4 & 31 & 3944 & 386 & 0,7 & 0,05 \\
\hline $29-51$ & $\mathrm{Bl} 1$ & $2.5 Y R 4 / 6$ & 50.0 & 21.4 & 28.6 & 4103 & 408 & 0,7 & 0,1 \\
\hline $51-81$ & $\mathrm{Bl} 2$ & $2.5 Y 6 / 2$ & 48.7 & 21.3 & 30 & 4393 & 403 & 0,7 & 0,05 \\
\hline 81-100 & $\mathrm{Brl}$ & $2.5 \mathrm{Y} 6 / 2$ & 38.6 & 22.9 & 38.3 & 5097 & 434 & 0,8 & 0,1 \\
\hline \multicolumn{10}{|c|}{ Low Terrace (P6), Haplic Gleysol (Thionic), $14^{\circ} 04^{\prime} 21.2^{\prime \prime} \mathrm{N} / 016.10^{\prime} 51.6^{\prime \prime} \mathrm{W}$} \\
\hline $0-4$ & Ahz & 10YR2/3 & 82.1 & 12.8 & 5.1 & 2495 & 511 & 0,4 & 0,1 \\
\hline $4-32$ & Ahlz & 10YR2/2 & 67.6 & 21.8 & 10.5 & 2936 & 409 & 0,5 & 0,1 \\
\hline $32-62$ & $\mathrm{Bl} 1$ & 10YR4/6 & 71.0 & 20.0 & 8.8 & 2608 & 368 & 0,4 & 0,05 \\
\hline $62-82$ & $\mathrm{Bl} 2$ & 10YR5/6 & 68.6 & 17.2 & 14.3 & 2610 & 320 & 0,4 & 0,04 \\
\hline $82-110$ & $\mathrm{Brl}$ & 10YR4/6 & 61.7 & 12.4 & 26 & 3089 & 320 & 0,5 & 0,04 \\
\hline \multicolumn{10}{|c|}{ Middle Terrace (P7), Endogleyic Arenosol, 140 04' 15.9”N / 016. 10'47.5”W } \\
\hline $0-26$ & Ap & 10YR3/4 & 85.1 & 9.7 & 5.1 & 2114 & 300 & 0,3 & 0,04 \\
\hline $26-60$ & $\mathrm{Ah}$ & 10YR3/4 & 79.8 & 1.0 & 6.2 & 2534 & 355 & 0,4 & 0,05 \\
\hline $60-108$ & Cw & $7.5 \mathrm{R} 8 / 3$ & 90.4 & 8.6 & 0.8 & 1066 & 204 & 0,2 & 0,03 \\
\hline $108-160$ & $\mathrm{Bl}$ & 7.5YR7/4 & 88.4 & 9.7 & 1.8 & 1368 & 241 & 0,2 & 0,03 \\
\hline \multicolumn{10}{|c|}{ Middle Terrace (P8), Endogleyic Arenosol, N 140 04' 14.0" / W 016. 10’ 47.1" } \\
\hline $0-31$ & Ap & 10YR2/2 & 77.6 & 15.3 & 7.1 & 2376 & 367 & 0,4 & 0,05 \\
\hline $31-62$ & $\mathrm{AhC}$ & 10YR3/2 & 78.8 & 18.3 & 3 & 2447 & 456 & 0,4 & 0,1 \\
\hline $62-107$ & $1 \mathrm{Cw}$ & 7.5YR7/3 & 82.1 & 15.9 & 2 & 1384 & 301 & 0,2 & 0,04 \\
\hline $107-138$ & $2 \mathrm{Bl}$ & 10YR6/3 & 72.9 & 10.7 & 16.4 & 2698 & 409 & 0,4 & 0,1 \\
\hline $138-160$ & $1 \mathrm{Bl}$ & 10YR8/2 & 83.5 & 12.5 & 4.3 & 1239 & 265 & 0,2 & 0,04 \\
\hline \multicolumn{10}{|c|}{ Middle Terrace (P9), Endogleyic Arenosol, $14^{\circ} 04^{\prime} 14.0^{\prime \prime} \mathrm{N} / 016.10^{\prime} 47.2^{\prime \prime} \mathrm{W}$} \\
\hline $0-36$ & Ap & 10YR2/3 & 67.5 & 18.2 & 14.3 & 3558 & 684 & 0,6 & 0,1 \\
\hline $36-67$ & $\mathrm{Ah}$ & 10YR3/3 & 64.6 & 20.3 & 15.1 & 3575 & 670 & 0,6 & 0,1 \\
\hline $67-88$ & $\mathrm{Cv}$ & 10YR4/3 & 70.1 & 17.4 & 12.5 & 3452 & 582 & 0,6 & 0,1 \\
\hline $88-126$ & $\mathrm{Bc}$ & 10YR5/4 & 64.9 & 20.5 & 14.6 & 3667 & 641 & 0,6 & 0,1 \\
\hline $126-160$ & $\mathrm{Bl}$ & $2.5 Y 3 / 2$ & 61.4 & 14.5 & 24.1 & 3626 & 517 & 0,6 & 0,1 \\
\hline
\end{tabular}



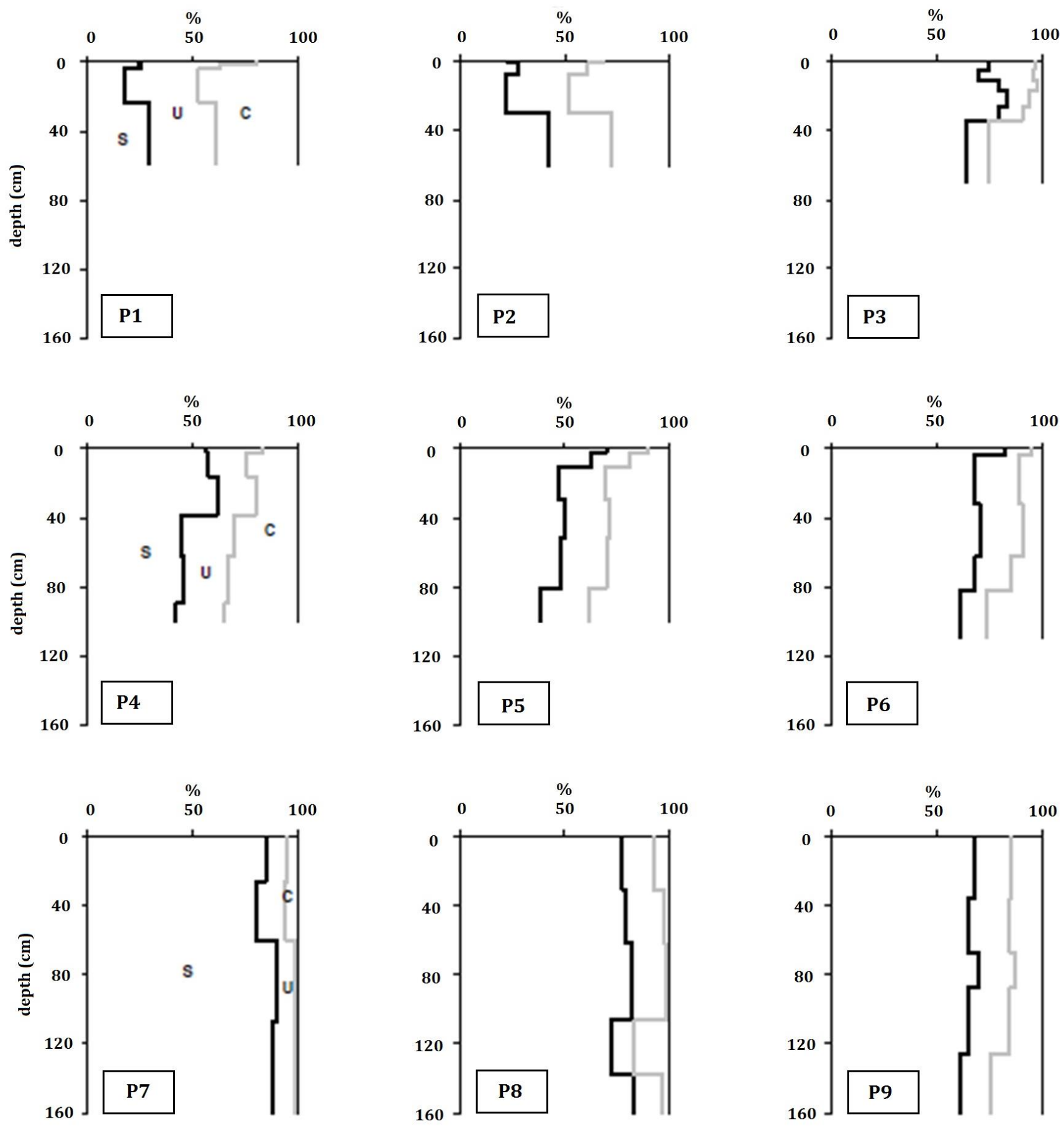

Figure 2. Particle size distribution with depth in the floodplain (P1-P3), low terrace (P4-P6), and middle terrace (P7-P9) profiles. $\mathrm{S}=$ sand; $\mathrm{U}=$ silt; $\mathrm{C}=$ clay

\section{Ratio of $\mathbf{m S} /(\mathbf{c U}+\mathbf{m U})$}

"Dust" is a term that refers to silt-size or smaller sediment that has an eolian origin (Simonson, 1995). The depth distributions, particularly of silt and clay, provide good clues as to the soil-forming processes and factors operating at the site, and thus help ensure that pedogenesis, rather than some parent-material layering that can mimic pedogenesis, has taken place (Birkeland, 1999). Particle-size distribution can help to identify the contribution of eolian fines to the soil surface. Simonson (1995) demonstrated that many soils carry the imprint of a dust contribution. In many localities, even those far removed from eolian source areas, parent-material layering might be due to eolian deposition (Birkeland, 1999).

The $\mathrm{mS} /(\mathrm{cU}+\mathrm{mU})$ ratio was applied to estimate the importance of silt-size material in soil profiles. Floodplain profiles show lower $\mathrm{mS} /(\mathrm{cU}+\mathrm{mU})$ values in the topmost horizons (Figure 3$)$. Values decrease generally with depth in the low terrace profiles, The highest values of $\mathrm{mS} /(\mathrm{cU}+\mathrm{mU})$ were obtained in the middle terrace profiles, mainly in the subsoil of P7 and P8 (Table 1, Figure 3). 

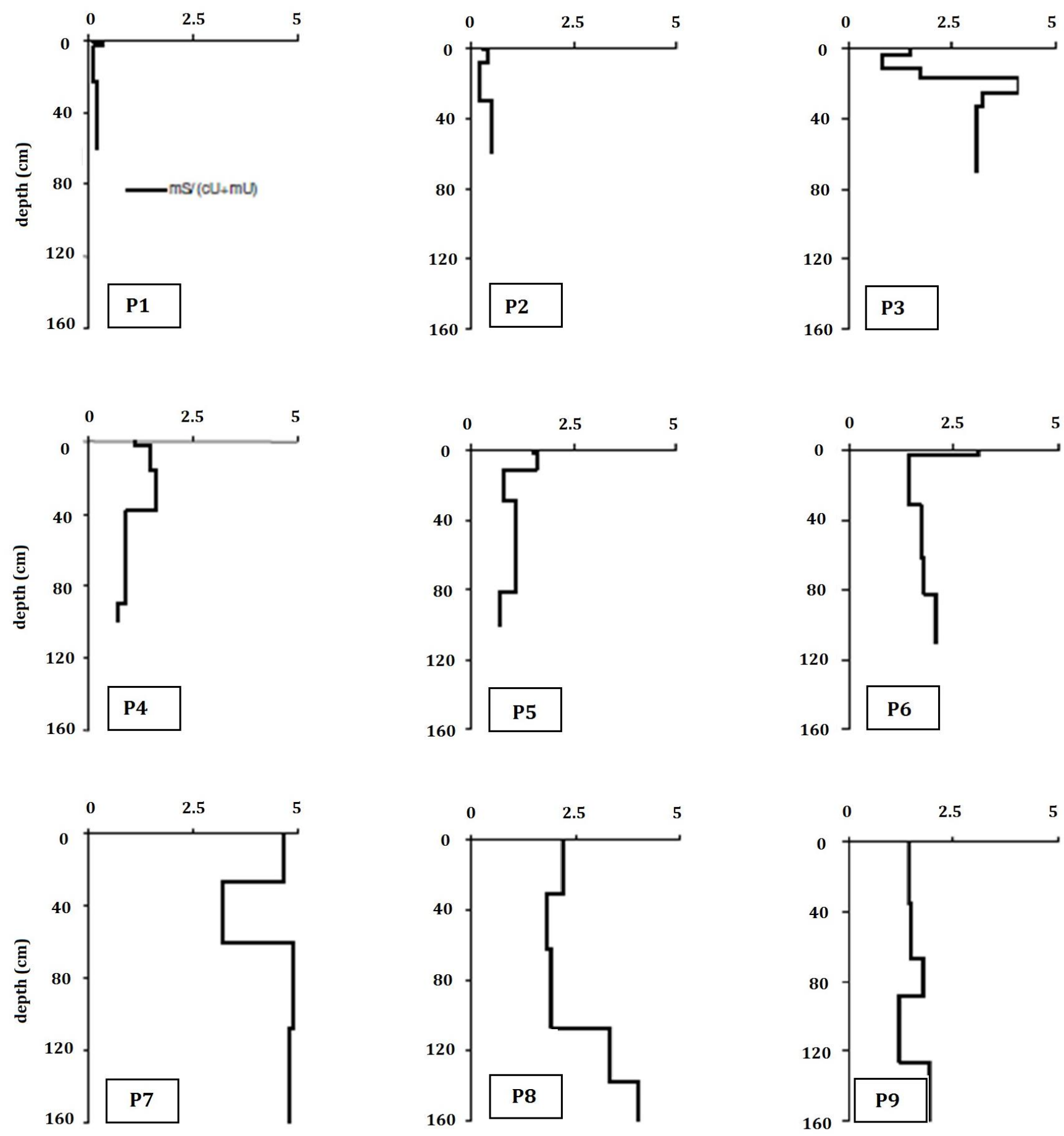

Figure 3. Depth function of $\mathrm{mS} /(\mathrm{cU}+\mathrm{mU})$ ratio in the floodplain (P1-P3); low terrace (P4-P6); and middle terrace (P7P9) profiles

The topmost horizons of the floodplain profiles show a silt-rich mantle (lowest $\mathrm{mS} /(\mathrm{c} U+\mathrm{mU})$ ratios); supporting addition of allochtonous material. This silty mantle is also identifiable in the topsoil of low terrace profiles. Values of $\mathrm{mS} /(\mathrm{cU}+\mathrm{mU})$ vary however within this latter landscape position; with the highest values yielded in P6 and the lowest values in P4 (Figure 3). This suggests variable intensity of colluvium addition in soil profiles on this landscape position. So the sandy mantle decreases seaward, while the silty mantle increases in the same direction. Eolian dust inputs seem the likeliest accountable factor for such distribution pattern. This suggests that thickness and fineness of the eolian mantle is a function of distance from the source site. Globally the incidence of dust additions in soil profiles is determined by the distance between source area and accumulation site (Schaetzl and Anderson, 2005). McTainsh et al. (1997) investigated the contribution of eolian accessions in soils of Mali, West-Africa. They found dust deposition 
being function of particle size with long-distance deposition producing fine deposits (mainly $<5 \mu \mathrm{m}$ ); while dust from regional sources produce deposits mainly in the size range 20-40 $\mu \mathrm{m}$, and local dusts produce relatively coarse material in the size range $50-70 \mu \mathrm{m}$. The transported material concerns, thus, mainly the silt-fraction $(2-63 \mu \mathrm{m})$, and to a lesser extent, the clay $(<2 \mu \mathrm{m})$ and very fine sand $(63-200 \mu \mathrm{m})$. Based on this argumentation (finding) we assume that regional dust sources (from the surrounding Continental Terminal plateau) play the determining role regarding the supply of allochtonous material in the study area, whereas local (Saloum region) and long-distance (Sahara) dusts appear less critical. Herrmann (1996), Middleton and Goudie (2001) and Goudie and Middleton (2001) identified two source areas for major dust events which could interest West Africa region: the Bodele depression and an area covering eastern Mauritania, western Mali and southern Algeria. Dust is transported from the southern Sahara Desert over the West African savanna and across the tropical Atlantic Ocean (Prospero and Carlson, 1972; Jaenicke and Schutz, 1978; Prospero et al., 1981). These long-range transports of dust are supposed to permanently feed soil material in our study area. Their nature as well as their individual contribution in local soil development remains to be investigated. Resolution of such questions is, however, outside the scope of the present study. It requires detailed regional studies.

\section{The $\mathrm{Ti} / \mathrm{Zr}$ ratio}

Soil uniformity was secondly tested using the Ti/Zr ratio. Many studies (Raeside, 1959; Alexander et al., 1962; Reheis, 1990) demonstrated $\mathrm{ZrO} 2$ to be more resistant to weathering than any other commonly occurring oxide in soils. Likewise, Harden (1988) found zirconium to be the most stable element, since zircon grains remained remarkably unchanged with no increased etching with time. She used zirconium as reference to show changes in soil composition, and found indications for eolian deposition on fluvial terraces in central California by an increase of the ratio over time.

Also, due its low mobility during chemical weathering, Ti is commonly associated with Zr to evaluate parentmaterial uniformity within soil profiles presenting no evidence of translocation of silicate clay, i.e. without $\mathrm{Bt}$ horizons, as those being studied; because the titanium oxides are observed to partially co-illuviate with the clay fraction towards the Bt-horizons (Chapman and Horn, 1968; Smeck and Wilding, 1980; Wagner, 2009). The Ti/Zr ratio figured out two main trends in the present study: (1) nearly constant values within the floodplain and middle terrace profiles and (2) gradual downward increase in the low terrace profiles. Similar values are obtained in the floodplain (except for the topsoil of P3) and subsoil of low terrace profiles $(9<$ $\mathrm{Ti} / \mathrm{Zr}<13$ ), while the middle terrace soils share approximately the same values with the topsoil of low terrace profiles $(4<\mathrm{Ti} / \mathrm{Zr}<10)$ (Table 1 , Figure 4$)$. This gives insight into the nature and origin of soil material in our study area.

We attributed the textural features at landscape scale and within soil profiles to mainly two different sources of soil material: marine and continental. Marine sediments compose the floodplain profiles (soil material) and the subsoil of low terrace profiles, while the colluvial material derived from continental uplands form the middle terrace profiles and the topsoil of low terrace profiles. The TCS in the low terrace profiles accounts for this colluvio-alluvial origin of sediments on this intermediate landscape position. Assess the contribution of each source appears however complex due to the possible mixing between allochtonous and materials derived in situ in soil profiles. This alters the normal pathway of soil development, making homogeneity tests of parent material in coastal areas more intricate. Determining the homogeneity of soils developed from unconsolidated materials in semiarid and arid regions poses serious problems because of different source areas and the pronounced episodic nature of deposition (Allen and Hajek, 1989).

Application of the Ti/Zr ratio gives nevertheless additional insights regarding the texture contrasts analysed above. It mainly confirms the presence of discontinuities in soil parent material on the low terrace site. These discontinuities may be, according to the available sedimentologic and geochemical data, located at ca. $38 \mathrm{~cm}$ depth in $\mathrm{P} 4,11 \mathrm{~cm}$ and $51 \mathrm{~cm}$ in P5, $4 \mathrm{~cm}$ and $82 \mathrm{~cm}$ in P6. They remain less pronounced in the floodplain profiles (23 cm in P1, $30 \mathrm{~cm}$ in P2, and $34 \mathrm{~cm}$ in P3); and were not identified in the middle terrace profiles (Figure 2, 3, and 4). This represents however a general distribution trend of soil material, because colluvial sediments may be identified on all landscape positions; their influence decreases seaward, being less significant on the floodplain location. 

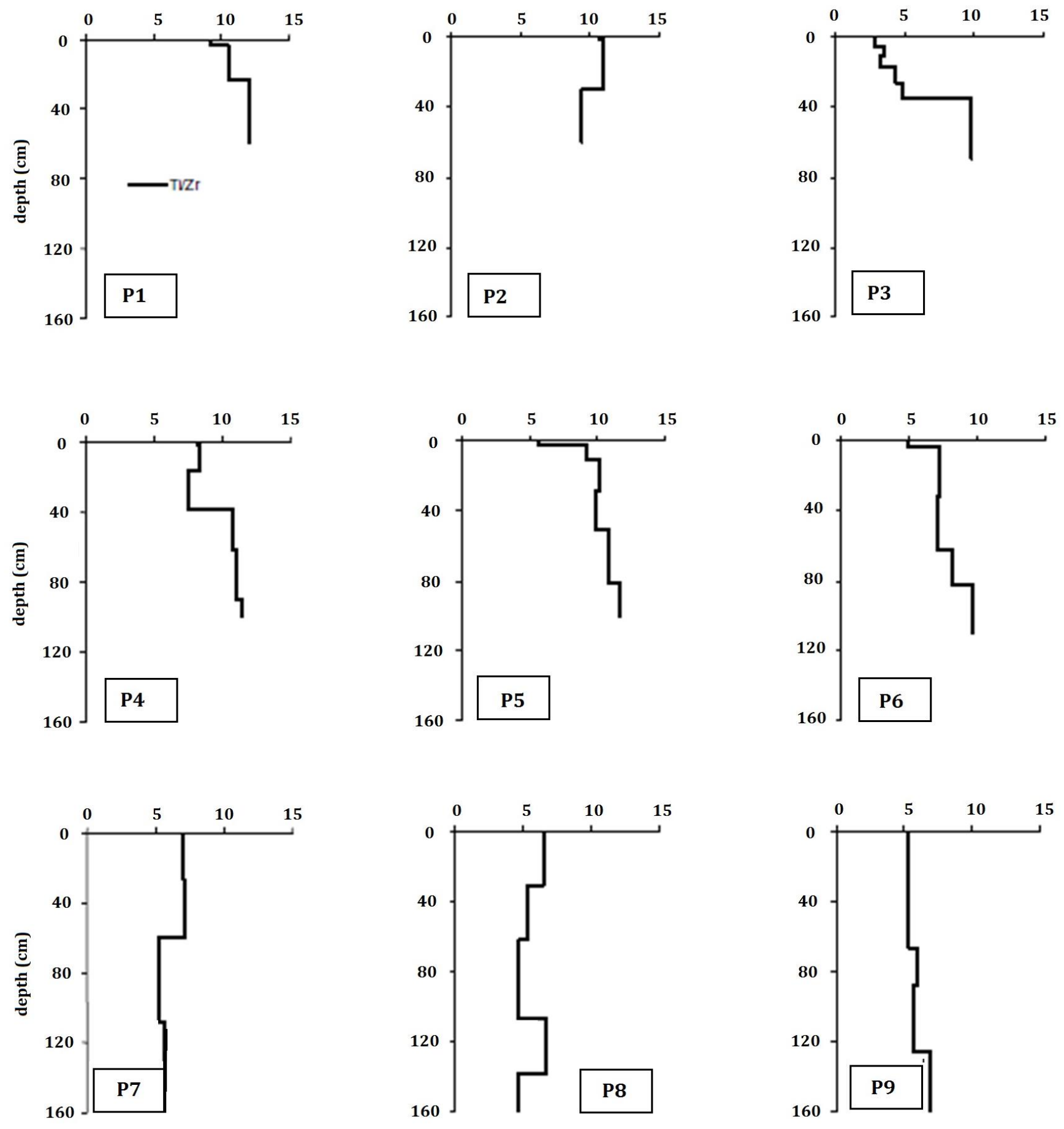

Figure 4. Depth function of Ti/Zr ratio in the floodplain (P1-P3); low terrace (P4-P6); and middle terrace (P7-P9) profiles

\section{Conclusion}

The present study demonstrates the presence of TCS in the coastal area of the Saloum river basin, west central Senegal, West Africa. We attributed the formation of these TCS to mainly two different sources of soil material: marine and continental. Marine sediments build the floodplain profiles and the subsoil of low terrace profiles, while the colluvial material derived from continental uplands form the middle terrace profiles and the topsoil of low terrace profiles. The TCS of the low terrace profiles accounts for this colluvioalluvial origin of sediments on this intermediate landscape position. The main finding remains the influence of eolian dust inputs on the formation of TCS in this coastal area. Evidence of airborne addition suggested by particle size distribution was confirmed by the uniformity of soil parent material tested through $\mathrm{mS} /(\mathrm{cU}+\mathrm{mU})$ and $\mathrm{Ti} / \mathrm{Zr}$ ratios. They give insights into the origin and nature of sediments in the study area. Such knowledge enhances understanding of pedogenesis in coastal areas worldwide and may help develop sustainable soil management strategies. 


\section{References}

Abate, N., Kibret, K., 2016. Effects of land use, soil depth and topography on soil physicochemical properties along the toposequence at the Wadla Delanta Massif, Northcentral Highlands of Ethiopia. Environment and Pollution 5 (2): 57-71.

Ahn, P.M., 1970. West African Soils. Vol.1, 3rd Edition, Oxford University Press, Oxford GB, 315p.

Alexander, J.D., Beavers, A.H., Johnson, P.R., 1962. Zirconium content of coarse silt in loess and till of Wisconsin age in northern Illinois. Soil Science Society of America Journal 26(2): 189-191.

Allen, B.L., Hajek, B.F., 1989. Mineral occurrence in soil environments. In: Minerals in Soil Environments. Dixon, J.B., Weed, S.B. (Eds.). Book Series No.1, Soil Science Society of America, Madison, Wisconsin, USA, pp. 199-278.

Bald M. 2012. Development of textural differentiation in soil: a quantitative analysis. Thesis for an Honours Degree in Environmental Geoscience, University of Adelaide, Australia, 68p.

Barusseau, J.P., Ba, M., Descamps, C., Diop, E.H.S., Giresse, P., Saos, J.L., 1995. Coastal evolution in Senegal and Mauritania at $10^{3}, 10^{2}$ and 101-year scales: Natural and human records. Quaternary International 29-30: 61-73.

Baskan, O., Dengiz, O., Gunturk, A., 2016. Effects of toposequence and land use-land cover on the spatial distribution of soil properties. Environmental Earth Science 75:448.

Birkeland, P.W., 1999. Soils and geomorphology. $3^{\text {rd }}$ edition; Oxford University Press, Oxford, England, 448p.

Chapman, S.L., Horn, M.E., 1968. Parent material uniformity and origin of silty soils in northwest Arkansas based on zirconium-titanium contents. Soil Science Society of America Journal 32(2): 265-271.

Dengiz, O., Hüseyin, SS., 2018. Effect of toposequences on geochemical mass balance and clay mineral formation in soils developed on basalt parent material under subhumid climate condition. Indian Journal of Geo Marine Sciences 47 (9): 1809-1820.

Diop, E.S., 1986. Tropical Holocene estuaries. Comparative study of the physical geography features of the rivers from the south of Saloum to the Mellcoree (Guinea Republic). These es Sciences, University L Pasteur Strasbourg, France, 379p.

Fall, A.C.A.L., Montoroi, J.P., Stahr, K., 2014. Coastal acid sulfate soils in the Saloum River basin, Senegal. Soil Research 52(7): 671-684.

Faye, S., Faye, S.C., Ndoye, S., Faye, A., 2003. Hydrogeochemistry of the Saloum (Senegal) superficial coastal aquifer. Environmental Geology 44: 127-136.

Goudie, A.S., Middleton, N.J., 2001. Saharan dust storms: nature and consequences. Earth-Science Reviews 56(1-4): 179204.

Harden, J., 1988. Genetic interpretations of elemental and chemical differences in a soil chronosequence, California. Geoderma 43: 179-193.

Hardie, M., Doyle, R.B., Cotching, W., Lisson, S., 2012. Subsurface Lateral Flow in Texture-Contrast (Duplex) Soils and Catchments with Shallow Bedrock. Applied and Environmental Soil Science Article ID 861358.

Herrmann, L., 1996. Staubdeposition auf Boden West-Afrikas. Eigenschaften und Herkunftsgebiete der Staube und ihr Einflus auf Boden- und Standortseigenschaften. Hohenheimer Bodenkundliche Hefte 36, Hohenheim, 239 p,

IUSS Working Group WRB, 2015. World Reference Base for Soil Resources 2014, update 2015. International soil classification system for naming soils and creating legends for soil maps. World Soil Resources Reports No. 106. Food and Agriculture Organization of the United Nations (FAO), Rome, Italy. 192p. Available at [access date: 14.03.2019]: http://www.fao.org/3/i3794en/I3794en.pdf

Jaenicke, R., Schutz, L., 1978. Comprehensive study of physical and chemical properties of the surface aerosols in the Cape Verde Islands region. Journal of Geophysical Research 83(C7): 3585-3599.

Jones, M.J., Wild, A., 1975. Soils of the West African Savanna. Oxford University Commonwealth Agricultural Bureaux, England, $246 \mathrm{p}$.

Kalck, Y., 1978. Evolution des zones de mangroves à Sénégal au Quaternaire recent: Etudes géologiques et géochimiques et géochimiques. Unpublished Thesis, University of Louris Pasteur, Strasbourg, France.

Langley-Turnbaugh, S.J, Bockheim, J.G., 1997. Time-dependent changes in pedogenic processes on marine terraces in coastal Oregon. Soil Science Society of American Journal 61(5): 1428-1440.

Lappartient, J.R., 1985. Le Continental Terminal et le Pléistocène ancien du Bassin sénégalo-mauritanien. Stratigraphie, sédimentation, diagenèse, altérations. Reconstitution des paléorivages au travers des cuirasses. Thesis, University. Aix-Marseille III, 294 p.

Lézine, A-M., 1997. Evolution of the West African mangrove during the Late Quaternary: A review. Géographie physique et Quaternaire 51: 405-414.

McTainsh, G.H., Nickling, W.G., Lynch, A.W., 1997. Dust deposition and particle size in Mali, West Africa. Catena 29: 307322.

Michel, P., 1975. Les bassins des fleuves Senegal et Gambie: étude géomorphologique. Revue Géographique de l'Est Année 15(1-2) : 237-242 [in French].

Middleton, N.J., Goudie, A.S., 2001. Saharan dust: sources and trajectories. Transactions of the Institute of British Geographers 26(2): 165-181.

Milne, G., 1936. A provisional Soil Map of East Africa (Kenya, Uganda, Tanganyika and Zanzibar) with Explanatory Memoir. Amani Memoirs, London. 
Mulugeta, D., Sheleme, B., 2010. Characterization and Classification of Soils along the Toposequence of Kindo Koye Watershed in Southern Ethiopia. East African Journal of Sciences 4(2): 65-77.

Paton, T.R, Humphries, G.S., Mitchell, P.B., 1995. Soils: A New Global View. CRC Press, New York, USA. 83p.

Petters, S.W., 1991. Regional geology of Africa. Springer, Heidelberg, 722p.

Phillips, J.D., 2001. Contingency and generalization in pedology, as exemplified by texture-contrast soils. Geoderma 102(3-4): 347-370.

Phillips, J.D., 2007. Development of texture contrast soils by a combination of bioturbation and translocation. Catena 70(1): 92-104.

Prospero, J.M., Carlson, T.N., 1972. Vertical and aeral distribution of Saharan Dust over the Western Equatorial North Atlantic Ocean. Journal of Geophysical Research 77(27): 5255-5265.

Prospero, J.M., Glaccum, R.A., Nees, R.T., 1981. Atmospheric transport of soil dust from Africa to South America. Nature 289: 570-572.

Raeside, J.D., 1959. Stability of index minerals in soils with particular reference to quartz, zircon, and garnet. Journal of Sedimentary Petrology 29(4): 493-502.

Reheis, M.C., 1990. Influence of climate and eolian dust on the major-element chemistry and clay mineralogy of soils in the Northern Bighorn Basin, USA. Catena 17(3): 219-248.

Retallack, G.J., 1990. Soils of the past. An Introduction to Paleopedology. John WileySons. Inc., London, UK. 520p.

Schaetzl, R.J., Anderson. S., 2005. Soils: Genesis and geomorphology. University Press, Cambridge, UK, 817p.

Schlichting, E., Blume, H.P., Stahr, K., 1995. Bodenkundliches Praktikum. Blackwell Wissenschafts-Verlag, Berlin, Wien, $295 \mathrm{p}$.

Simonson, R.W., 1995. Airborne dust and its significance to soils. Geoderma 65(1-2): 1-43.

Smeck, N.E., Wilding, L.P., 1980. Quantitative evaluation of pedon formation in calcareous glacial deposits in Ohio. Geoderma 24(1): 1-16.

Tijjani, M.A., Hassan, I.M., 2017. Variability of some soil properties along toposequence on a basaltic parent material of Vom, Plateau State, Nigeria. International Journal of Scientific \& Technology Research 6 (2): 22-26

Tunçay, T., Dengiz, O., Imamoğlu, A., 2020. Influence of toposequence on physical and mineralogical properties of soils developed on basaltic parent material under sub-humid terrestrial ecosystem. Journal of Agricultural Sciences 26(1): 104-116.

Wagner, S., 2009. Soil (Chrono-) Sequences on Marine Terraces - Pedogenesis in two coastal areas of Basilicata and Agrigent, Southern Italy. Hohenheimer Bodenkundliche Hefte 93, Hohenheim, 314p.

Walker, P.H., Chartres, C.J., Hutka, J., 1988. The effect of eolian accessions on soil development on granitic rocks in South-Eastern Australia. I. Soil morphology and particle-size distributions. Australian Journal of Soil Research 26(1): 1-16.

Wright, J.B., Hastings, D.A., Jones, W.B., Williams, H.R., 1985. Geology and mineral resources of West Africa. George Allen \& Unwin Publishers. London, UK. 188p. 